\title{
Estudio educativo sobre el efecto del tiempo desconocido en el compromiso del derecho iraní y los documentos internacionales
}

\section{Educational study on the effect of unknown time on compromise of Iranian Law and International Documents}

\author{
Siavash Sharbati ${ }^{1}$, Ebadullah Rostami $^{2 a}$, and \\ Seyed Mohammad Asadi Nejad ${ }^{3}$ \\ Department of Private Law, Rasht Branch, Islamic Azad University, Rasht, Iran ${ }^{12}$ \\ Department of Law, Gilan University, Gilan, $\operatorname{Iran}^{3}$ \\ Orcid ID: https://orcid.org/0000-0002-9623-3583 ${ }^{1}$ \\ Orcid ID: https://orcid.org/0000-0002-4632-8058 \\ Orcid ID: https://orcid.org/0000-0001-5407-779X 3
}

Recibido: 12 de mayo de 2020

Aceptado: 19 de enero de 2021

\begin{abstract}
Resumen
El objetivo de este estudio fue el efecto del tiempo desconocido sobre el compromiso en la ley iraní y los documentos internacionales. Lo cual se ha hecho en un método de biblioteca y mediante la revisión de los documentos. Sin embargo, es razonable que la implementación del compromiso en tales circunstancias en documentos internacionales sea razonable y estándar. Para documentos internacionales: el artículo 33 de la Convención de las Naciones Unidas sobre la Compraventa Internacional de Mercaderías (CISG), los Contratos de Comercio Internacional (UPICC), el artículo 107-27 de la Ley de Tratados Europeos (PECL) y el artículo 102-22 del Marco Común de DCFR de Referencia). Después de concluir el contrato, considerando todos sus términos y condiciones esenciales, por cualquier motivo, de manera deliberada o involuntaria, una de las partes puede negarse a ejecutar el contrato con el pretexto de que el contrato es inaplicable y la ley civil parece silenciosa. Lo hace, y no hay una solución explícita para nuestro derecho civil, a pesar de lo estipulado en documentos internacionales.
\end{abstract}

Palabras clave: Legislación iraní, comercio internacional, derecho civil, tiempo legal, Irán Abstract

The aim of this study was the effect of unknown time on commitment in Iranian law and international documents. Which has been done in a library method and by reviewing the documents. It is reasonable, however, that the implementation of the undertaking in such

${ }^{a}$ Corresponding Author E-mail: rostami561@ gmail.com 
circumstances in international documents is reasonable and standard. For International Documents: Article 33 of the United Nations Convention on the International Sale of Goods (CISG) International Trade Contracts (UPICC), Article 107-27 of the European Treaty Law (PECL) and Article 102-22 of the DCFR Common Framework of Reference). After concluding the contract, considering all its essential terms and conditions, for any reason, deliberately or unintentionally, one of the parties may refuse to execute the contract on the pretext that the contract is unenforceable, and the civil law seems silent. It does, and there is no explicit solution to our civil law, despite the stipulation in international documents.

Keywords: Iranian law, international trade, civil law, legal time, Iran

\section{Introduction}

Whether in domestic or international law, because of negligence or willful or because of the complexity and sophistication of the legal relations of the successors, many of the requirements relating to obligations, including the time when the obligation is enforced, are vague and uncertain, However, the contract really has the essentials of authenticity and is a formed word. Or by custom, the will of the parties is to create a perfect contract (Khorsandian and Nasripour, 2014).

Most of the jurisprudents consider the unknown time to be null and void, so the opinions of the jurists are examined in this article. The two most important articles on the subject matter are: 1- Paragraph 2 of Article 233 BC; As for the unknown condition that ignorance causes ignorance to transgressors, the unknown time must be considered void. 2. Article 401 of the Civil Law on option stipulates that "if the stipulation is not fixed for option, both the cucumber condition and the nullity condition are invalid" (Tusi, 2018: 161).

In international documents, the principle is about the fulfillment of the obligation in case the contract is ambiguous and ambiguous, in this respect the matter has been brought into conformity with our civil law and domestic law. But the stage of contract formation seems to be separate from the stage of implementation, and the stage of implementation should not have any relation to the elements of the contract and ultimately to the contract to the extent that whatever the interlocutors intend and this intention and will is achievable and transmit the contract (Bozorgmehr, 2017). Invalid, so you must look for another rule unless the runtime is a commitment. In addition, it has been tried to present and respond to the case by analyzing the case (Katouzian, 2007). So, there are issues of the day that are related to lawyers, lawyers, judges, legal and real estate consultants as well as those involved in such cases. Finally, it should be noted that in this article, the view of jurists, legal scholars, and then in the international documents on the 
subject from various angles and to the extent of answering the questions and reaching the answer to the main question, is analyzed and then the personal opinion with Attention has been paid to the tangible benefits of the community that I have actually experienced. However, there will undoubtedly be further criticisms and comments in the future.

\section{Methodology}

The most common method of gathering information in the field of law is the library method. In the library research method, the researcher, referring to authoritative books and wellknown and authoritative authors, documents, journals and newspapers, files his findings, keeps the loan in quotation marks in parentheses, and quotes its tariff and reference in a footnote (Katouzian, 2007). In legal writings, the author's role is more to extract the rules from the sum of the materials and to show the principles that guided the legislator in compiling and composing them. The researcher, by analyzing the judicial procedure and exploring the reasons for the legislator's ruling, arranges such matters in such a way that in cases of conciseness and contradiction of materials, the spirit of the law can be easily obtained and various lawsuits can be resolved with the existing rulings (Alidoust, 2000).

The method of research in the science of law is the arrangement and arrangement of legal writings in such a way that it is very little for scholars in this field who have a desire to compile and write literary and legal techniques (Habibi, 2017). The method of this research has been done in the form of a library in which the authors have reviewed and studied the objectives and questions of the research by examining the professor and the available documents, and in it they have tried to examine the documents using valid scientific methods. It is also answering research questions. (Khansari, 2017).

\section{Results}

\section{The jurists' opinion about the effect of the unknown time}

In this regard, jurists are divided into several groups:

1. The situation is the same in terms of the probability of an increase and a deficiency in runtime, such as the time it takes to execute a contract when it is shared between the two or to make it "Rabi" in the contract, the Rabi joint between Rabi al-Awl and Rabi Simply put, the marriage will be void. It is like a case of making a condition without defining the time (Safa'i, 
2007). In this case, the runtime seems to be clear and basically the Rabi is shipped over to the first Rabi, unless the contract is between Rabi al-Aval and Rabi al-Thani, which due to the passing of Rabi al-Aal, the run-time is shipped on Rabi al-Thani.

2. Some jurists believe that, even if the condition of permanent authority is, it is not unknown and ignorance of it does not cause ignorance to the transgressors. option that do not last for a long time carry over to the option immediately and disappear after a time in which it is possible to terminate the contract (Katouzian, 2011). Some jurists carry the indefinite term of three days and cite animal-related news (Nasiri et al, 2005). It is observed that the jurists do not have the same opinion about the uncertainty and the option condition, in other words, if the contract execution is uncertain, the shipment will be canceled and if the condition is not specified, it will be shipped on an immediate or three-day basis. At the same time, some jurisprudents consider the time between two or more instances to be correct and carry it on the first instance, since in this case, with the few instances in mind, the mystical time is the time of execution (Abedi, 2016). Waiting until the seller's turnaround seems to be not an indefinite time but rather a regular one, but given that the seller may never attempt to refill, the buyer can terminate the deal. Therefore, it is not possible to refer only to the obligation of a pledge or right and not to specify a time in the contract. Therefore, an indeterminable time in a way that cannot be determined is the indefinite term.

3. Jurists also disagree on the right to permanent and lifelong termination. There is disagreement among jurists as to whether or not the meaning of time is unknown or that the time of execution is unknown. Some have been incapable of definitive reasoning. But at a glance, according to the celebrity, the timing of the void is void. The jurists' argument in this regard is briefly as follows: If the term is unknown and the term is not specified, such as the entry of hajjs or as if I was selling to you provided I had options, or the term was mentioned in the absolute terms, for example I would sell you on condition that you buy cucumbers for a while. To be sure, in all cases, due to the boa's pride, they are equal in consequence of being void (Ansari, 2013).

\section{Time unknown in civil law}

In the civil law, there is no explicit reference to the unknown time, but wherever the obligation has been debated, the lawyers referred to paragraph 2 of Article 233 BC. Concerning the unknown condition or Article 401 of the said law on cucumber, the tendency is to invalidate 
the marriage and invalidate the marriage contract, because being ignorant leads to ignorance and, consequently, to the creation of pride. Civil law, of course, specifies the non-mention or nonpayment of the surcharge or the payment of the price. In any case, in accordance with Article 344 BC. In that case, the consequence is the present. That is, the obligation must be enforced immediately, unless, in accordance with the custom and custom of the place or custom of the business in commercial transactions, there is a condition or time limit for the execution of the order of successors at the same time. Even if it's not mentioned in the contract since then. Of course, in Article 514 BC. The contract for the lease for a specified period of time is specified (Khorsandian and Nasripour, 2014).

The meaning of the unknown is the timing of the unknown, but the meaning of the meaning is not to hesitate between two or more dates. It should be noted that in contracts whose nature is continuous, such as Article 514 of the Civil Code, it is different from Articles 233 and 401 of the Civil Code and it seems that mentioning the term is a condition and the essential pillar of the contract. In other words, in contracts where the time of commitment is the subject of commitment and the same thing, the obligation must be executed at the same time (Khorsandian and Nasripour, 2014). Contractual neglect such as Articles 691, 761 BC. Accordingly, the pledge and the peace treaty, based on goodwill and past, are not the subject of debate. Jurists also agree that the execution time should not be included in the contract. In the affirmative, it is also worth noting: If there is any doubt about the existence of the time of execution, the principle is that there is no time, and that the claimant must prove it, in accordance with Articles 344, 225 and 490 BC. It is mentioned in this regard (Mirshakari and Mutmadi, 2014).

\section{The nature of the unknown time on the fulfillment of the obligation}

The jurists are not unanimous about the nature of the execution of the obligation (contract, covenant) or legal event; in this respect, as far as the article is concerned, they have been used as follows:

1. Some jurists have found the fulfillment of the obligation to be justified and believe that in some cases it is necessary to fulfill that committed will. For example, religion before the time of execution. But sometimes one-sided legal fulfillment or legal action does not require committed will (Shahidi, 2014; Bahrami Ahmadi, 2017). 
2. Some other jurists, based on the well-known theory in France, consider that the obligation is fulfilled. Of course, based on the beliefs and habits of individualists, such ideas were and are intended to justify all social relations within the framework of the contract and to make the assumptions the basis of all obligations and institutions.

3. The majority of jurists believe that the execution of the obligation does not require a breach of contractual nature; the obligor, while performing the contract, is obliged to execute it; Forced to enforce the obligation. Except in some cases requiring legal or contractual action to be performed by one or both parties. Such as the obligation to sell property that is executed by a deed between the two parties (Katouzian, 2011). Some Egyptian lawyers argue that the contract is "as a law of conscience" for the judge to enforce the contract as a law and as a substitute for good faith (as a matter of law) (Senhori, 2015).

4. Some also seek to derogate from the moniker theories of unilateral obligation or contract or legal event and believe that the nature of executing a commitment is a two-pronged legal act and a commitment to doing the work of unilateral obligation (Khorsandian and Nasripour, 2014). Given that it has a pre-requisite obligation to hand over finance to another or to do something, it is neither free to choose the recipient nor to choose the amount and quality of the property (Katouzian, 2011). Therefore, the theory of the event of the legality of the nature of the performance of the obligation is superior to other theories.

\section{The effect of aleatory when executing a commitment from jurists}

The reason that the jurists regard the time of the obscure execution as void is aleatory, while they still disagree on the concept and interpretation of aleatory and its application to some contracts. Collectively, in the definition of aleatory they say: aleatory is the probability (risk) that custom avoids (Ansari, 2013; Khoi, 1417). Prohibition of aleatory also means guidance, government, or reverence. Some regard the prohibition of aleatory as a prohibition of guidance (Ansari, 2013); that is, it is forbidden in the event of ignorance and danger. Some have absolutely objected to reverence (Khansari, 1276). Some regard the prohibition of Rumi as prohibition of dignity and at other times the prohibition of guidance (Ansari et al, 1413; Mousavi Khomeini, 1421), and others regard the prohibition of aleatory as the prohibition of government (Habibi, 2017). 
Imam says that aleatory in the sense of "risk" is a "deceitful" deceit, one that is not committed and reliable, one that has a deceptive and esoteric appearance, and in the interpretation of aleatory means “danger” all. Deception returns (Khomeini, 1421), but elsewhere, it is doubtful at first sight that turning all meanings into one meaning and generalizing to the intended meaning is something that cannot be agreed upon unless it is invoked by the companions and this is weakness, but nevertheless It is difficult to accuse all jurists of wrongdoing, as it is also difficult to follow them without cause. Consideration should be given to the circumstances of the loss and "arrogance" when it comes to the execution of the obligation and the timing of the execution, or if it is unknown or uncertain. For this reason, some believe that the necessity of eliminating the ambiguity of the dealings in Imamiyyah jurisprudence is proven by the wisdom of reason (Martine, 1995).

\section{The status of the unknown time and its effects on commitment}

The meaning of the unknown time is the contractual time. The legal time or time limit as well as the time or time limit for the dispute are not discussed. In short, the moratorium has an exception to the law and an exceptional aspect, but the just or judicial term is a general sentence and applies to all individuals and obligations (Shafi'i et al, 2019). Jurists have attempted to establish, in the view of the jurists, the nullity of the contract if it is not known and often referred to in paragraph 2 of Article 233 and Article 401 BC. They cite. In this section, their arguments and theories have been attempted to express themselves critically and to provide a more balanced view. Now the question comes to mind whether or not the unknown timing actually affects the contract? - Some jurists have referred to the unknown time based on Article 401 BC. Invalidate and invalidate the contract, stating its justification; if the execution time is unknown, the other party will not know how much to trust in the commitment of the party, or if the contract is more likely to be lost or unprofitable. Slow and this is the biggest ambiguity and "Aleatory" for contracting (Pour et al., 2014; Katouzian, 2007; Safai, 2010). Whether, for an indefinite period, or for an indefinite period. It is as if it were executed by traveling to one of the parties (Katouzian, 2011). Especially if the time interval is long, it causes the amount of semen to become obsolete (Bozorgmehr, 2017). This situation is called inflation (Shahidi, 2014). 


\section{The effect of aleatory on lawyers when executing a commitment}

Like jurists, jurists refer to the Prophet's aleatory as a reason for invalidating the execution time. Although its effect on contracts seems to be diminishing day by day, the bastards or one of them should not be a jerk, but they will be without effect. But aleatory is that the contract between the two probabilities is uncertain, so that one probability is provided for the transaction party, but the other probability does not reach its goal. Like aleatory to sell at market price or expert price (Maleki, 2015).

Some jurists believe that selling at market-day prices is negligently customary, provided it is not volatile and that it is not reliable because it relies on the unknown or is based on the pricing of the unknown unless it is highly variable. (Rafi'i, 1999), where the determination of the pillars and the method of calculation (criterion and criterion) itself is a form of determination. Because it destroys ignorance and pride and may be more appropriate and accurate than traditional practices, in other words, it creates a real balance between the value of exchange and exchange (Qasemzadeh, 2004).

\section{Habits and Customs}

Although customs are similar in the way they form the basis for the validity of the "common will of the contracting parties" and the potential for conflicting customs, custom is more circular and binding than custom. Contrary to the custom that the litigants have to prove. Implementation of customary rules such as law is the responsibility of the magistrate and does not require conscientious obedience, while the parties must be aware of the habit, while the custom cannot be invoked against third parties contrary to custom (Ahmadi, 2010). But in accordance with the appearance of Article $344 \mathrm{BC}$. It is considered the same. In the international arena and in the principles of international law, contrary to domestic law, unless the customary parties have chosen, the dispute resolution authorities cannot resort to a common custom in interpreting the contract. Paragraph 1 of Article 9 of the Vienna Convention 1980 is based on the consensus that the consensus is based on the interpretation of contracts to remove obscure and obscure points of contract terms and conditions. In this assumption it is the intentional and internal intent of the parties (Habibi, 2017).

There seems to be a rigor over the hesitation of the runtime and ultimately the void of commitment. Because one can resolve the doubts by referring to the situation, the preliminary 
negotiations of contract interpretation, and so on. In addition, the timing of the hesitant execution between the two times is the time delay that has entered into the will of the arbitrator and must inevitably be subject to customary arbitration and the determination of any type of contract and has a high stake and ambiguity in discovering the will.

Ordinarily the delivery of the goods within a reasonable time after the conclusion of the contract (paragraph c of Article 33 of the Vienna Convention) the performance of the contract within the regular time (paragraph 3 of Article 102-7 of the principles of European contract law) and during the period after the conclusion of the contract (Paragraph C Article 1-1-6 Principles of International Trade Contracts) Depends on the circumstances of each case, even if an undetermined time for delivery of goods is included (Darabpour, 2016).

\section{Discussion}

What is important in international documents is the interpretation of the contract (Habibi, 2017: 369). The following are, therefore, important in dealing with international disputes.

\section{Discovery of Implicit Conditions:}

1. The second part of the first paragraph of the International Documents, where it provides: "... or may be determined by contract", seems ambiguous, meaning that a specified time for performance of an obligation is not specified or that the performance is ambiguous. In such circumstances, the implicit and implied terms and conditions of the contract, regardless of whether the source of the will of the parties, the rule of law or custom, whether general or specific, are effective for interpreting the contract (Habibi, 2017).

\section{Interpretation according to common intention}

If the runtime is unknown, the most important principle is to accept the "requirement of integration" or "interpretation according to common intention". International Trade Principles in Articles 17-1-2, 1-4- and 3-4, in European Contract Law Principles in Articles 2.5-2, 102-5 to 1065 and Article 8 of the International Convention on Goods and in the Framework Framework

Reference subscriber specified. Unless the time of delivery of the goods or goods is specified, the undertaking is obliged to execute the obligation at the standard and reasonable time and its interpretation is in accordance with the joint intention of the conspirators to have a reasonable and standard term of about forty articles in the principles of international commercial contracts and 
about sixteen articles. The principles of European contract law have been repeatedly stated in the International Convention on the Commodity and the Common Framework of Reference, and expresses the importance of the standard time in international documents and customary time in our law, which is at the same time acceptable on the basis of circumstances.

\section{An unspecified incident}

Paragraph C Article 1-1-6 Principles of International Trade Law, Paragraph 3 Article 1027 Principles of European Law, Paragraph 1 Article 2-102 Draft Common Reference Framework (European Civil Code) and Article 9 Vienna Convention on the Time of Delivery of Goods It is an unclear incident that there is no such provision in our rights. In international documents, if the seller's duty to deliver the goods is tied to an unspecified incident. The seller's duty is limited to a reasonable period of time. Although our legal texts are alien to such terms, but tying the runtime to an unspecified event should not prevent the contract from being executed. Of course, if it is made in accordance with the law of marriage.

\section{Custom}

Tradition is in the process of interpretation as a means of discovering the real intention or some kind of an afterthought. It is always of serious concern. Business Practices and Conduct Practices, Consolidated Procedures between Traders in Certain Conditions and Acting Similarly in Paragraph 3 of Article 8 of the Vienna Convention; The European treaty is stipulated. By accepting the building conditions and with the help of custom, one can understand the behavior and actions of both parties before and after the conclusion of the contract, and the real purpose of the parties is to understand the use of the word rhetoric and to discover the inner will. Even in the context of being left unfulfilled during the commitment to prevent the collapse of the commitment.

\section{Situation}

In interpreting the common intention, things have a great impact. For example, Article 1025 of the Principles of European Law lists the circumstances, including the initial negotiations, the conduct of the parties after the conclusion, the nature and purpose of the contract and the interpretation previously given to similar conditions, the common practice among traders. The meanings given to the terms and conditions are the usual and ... results, which are effective when executing the obligation. Although some jurisprudents find explicit custom to be applicable, 
Article 9-2 of the International Commodity Convention also provides for implicit agreement in this regard (Alidoust, 2000).

\section{Contract ambiguity in terms of performance}

If the contract execution time is ambiguous, a way must be found to execute it. In the same way that was said. Conversely, the first criterion is the discovery of the common intention of the successors, otherwise the contract will be interpreted on the basis of some kind of criterion that collectively constitutes interpretation on the basis of mixed criteria. Whatever the ambiguity or ambiguity, whether the terms of the contract are ambiguous (ambiguity in terms and conditions of the contract containing multiple meanings) or ambiguity at the stage of performance of the contract (when it is executed) due to the lack of mutual intent of the parties, the international dispute resolution authorities shall interpret Contracts are resorted to (Habibi, 2017), in order to arbitrate and resolve disputes by clarifying the obscure and obscure points of the contract and determining the rights and obligations of the parties based on a common intention or content interpretation (Alidoust, 2000).

\section{Selected Rule: Assumption}

It was stated that, despite the essential conditions of the transaction, Article $190 \mathrm{~b}$. It must be interpreted in accordance with the implied and implied terms and conditions and the express terms and conditions of good faith and the fair dealing principle of the contract. Conventional, customary, parties' performance, circumstances, preparatory negotiations, post-contractual conduct, nature and purpose of the contract, meanings given to terms and conditions, etc., also highlighted ambiguous and obscure points of performance. Therefore, the unknown condition is invalid without causing void or corruption, so what it finds is "runtime" or "run".

1- According to Articles 225 and 344 BC Immediate - customary enforcement is a pledge, as rejected at the Yazd Judicial Session on 9/1/81 by the prominent jurists, while it affirms and affirms the Supreme Court's affirmative vote on No. 1400/15/44. It is not conventional. A company commits to doing the deed and gets its price and pay, but wants to do it whenever it wants, even though it has been years since the pay or price was made, and though it has been conditioned. It is observed that the unknown time of the predecessor is considered present and the commitment is bound to fulfill the obligation. 
2. If one of the co-conspirators proves another deadline. At the same time, the pledge holder must execute the pledge at the same time, in accordance with custom and within a reasonable time, without causing any excitement.

\section{Conclusion}

The assumption of the unknown time does not cause the contract to become contagious and, ultimately, to cause the aleatory of the contract; Citing paragraph 2 of Article 233 and Article 401 BC. It is not a valid condition for an unknown and option condition, but in accordance with Articles 225 and 344 of the said law and the principle of necessity and in accordance with Article $219 \mathrm{BC}$ and the "loyalty to the contract" rule which are in full development stage and have the essential conditions of transaction validity. That is, the assumption that the execution time is unknown has no bearing on the validity of the contract, as most law-practitioners hold about the "legality of the performance of the obligation" as to the legal nature of the obligation.

After the transaction has been concluded, the contractors will conclude the contract and the contract will be concluded on the basis of the common intention; due to the appearance of the terms and meanings of the contract, immediate, customary execution of the contract is the criterion, if it proves to be fulfilled in the contract. A fixed time and in the future, the time of execution of the contract is the same as the time of action, so the assumption of the time of execution in the realm of the dead is not examined and, in this way, the "complicating principle and sub-principle of the time of execution" will be protected.

\section{References}

Abedi, M. (2016). Ajlal in Contractual Obligations. Publisher: Publishing Corporation, First Edition. https://chapentesharat.ir/

Alidoust, A. (2000). The Negative Rule of aleatory in Transactions. Journal of Islamic Economics, 9, 75-89. http://eghtesad.iict.ac.ir/

Ansari Pour, M. A., Vald bigi, F., Hossein Alizadeh, M. (2014). Alienator and its application in contracts, SAMT publisher, Iran. https://samta.samt.ac.ir/

Ansari Pour. M. A., Farzad Waldbegi, M., Alizadeh, H, (2014). Alienator and its application in contracts. SAMT publisher, Iran. https://samta.samt.ac.ir/ 
Bahrami Ahmadi, H. (2017). Generality of Contracts and Contracts, Tehran: Nays Publishing, Second Edition. https://nashreney.com/

Bozorgmehr, A. A. (2017). Comprehensive Description of Comparative Obligations Law: Advanced Civil Period (Comparative Study of Iranian Civil Rights in Obligations with ...), Publisher: University of Justice, 1, 78-79. https://www.gisoom.com/book/11506172/

Darabpour, M. (2016). An Interpretation on International Law: The 1980 Vienna Convention,

Publisher: The Treasure of Knowledge. https://unesdoc.unesco.org/ark:/48223/pf0000116994_eng

Ghasemzadeh, S. M. (2017). Licensing Theory of Commitment and Obligation-The Methods of Obliging Obligation. Journal of Law. 5, 124-140. https://clc2int.com/obligation-mns-rslt/ Habibi, M. (2017). Interpretation of International Business Contracts. Publisher: Quantity, Third Edition. https://yektabook.com/category

Katouzian, N. (1997). General Rules of Contracts, Publishers. Publishing Corporation, Bahman Borna, 2, 391-397. https://www.bahmanborna.ir/

Katouzian, N. (2007). General Rules of Contracts. Tehran: Mizan Publishing, Volume 2, Sixth Edition. http://www.mizan-law.ir/

Katouzian, N. (2011). General Rules of Contracts (Contract Implementation). Tehran: Publishing Joint Stock Company, Sixth Edition. https://www.entesharco.com/

Khansari, M. B., bin Mohammad, R. (2017). Al-Javma'i al-Faghih. Qom: The Library of the Holy Threshold of Hazrat Mas'umah (AS). http://www.lib.ir/library/294

Khorsandian, M. A., Nasiripour, R. (2014). Early Implementation of Commitments in Iranian Jurisprudence and Law, Razavi University of Science publisher, Iran. https://behnashr.razavi.ir/

Maleki, J. (2016). aleatory and aleatory Transactions, Courts of Law, Tehran: Publishing Haq Gostar Legal Articles. http://parstools.com/linkdirectory/haghgostar

Martine, E. H. (1995). a concise dictionary of law, 2 ed, Oxford University. https://global.oup.com/?cc=ir

Mirshakari, A. (2014). Aglow in legal practice. SAMT publisher, Iran. https://samta.samt.ac.ir/ Mousavi Khomeini, R. (1989). Al-Bai. Tehran: Institute of Organizing and Publishing Imam Khomeini's Works. https://www.icpikw.ir/ 
Nasiri, M., Tafreshi, M. A., Rostami Chalkasri, A. (2005). A Comparative Study of the Prisoners' Rights in Internal Law and the Fidic Model Contract. Journal of the Faculty of Humanities, 41, 167-179. http://ensani.ir/fa/article/8523

Safai, S. H. (2007). Basic Law of Civil Law General Rules of Contracts, Sixth Edition. Law Foundation of Meta-Tehrani, University of Tehran. https://press.ut.ac.ir/

Senhouri, A. R. (2009). Obligations Rights Period. Publisher: Qom University Press, Vol. 3. https://www.ketabcity.com/BookList.aspx?Type=PubRefid\&Code=13921

Shahidi, M. (2014). On Contract and Obligation. Volume Two, Sixth Edition, Publisher: Majd Publishing. http://www.majdlaw.ir/

Tusi, M. B. H. (2018). Al-Mabsut Fiqh Al-Amamieh. Publisher: Maktab al-Mortazavi, Tehran, Iran. https://toosbook.ir/p 